\title{
ÇALIŞANLARIN AMİRDEN TATMINI GÖREV PERFORMANSLARINI ETKİLER Mİ? SAVUNMA ALANINDA BIIR KURUMDA UYGULAMA
}

\author{
Mehmet KAHYA*
}

$\ddot{\boldsymbol{O}} z$

\begin{abstract}
Bu çalışmanın amacı, çalışanların amirden tatminleriyle görev performansları arasındaki ilişkiyi ortaya koymaktır. İs tatmininin ardıllarından birisi de görev performansıdır. Çalışanlarla amirleri arasında pozitif bir ilişki olması, çalışanların iş yerine ve amirine karşı olumlu tutum geliştirmesini sağlar. Tutumlar davranışlara yol açar ilkesinden hareketle de çalışanların işs tatmini gibi olumlu tutumlarının davranışlara yansıyarak performans artışına yol açacağı söylenebilir. Bu ilişkiyi test etmek maksadıyla savunma alanında faaliyet gösteren bir kurumun 274 çalışanı üzerinden veri toplanmıştır. Araştırmada elde edilen verilerin analizinde SPSS 22.0 istatistik paket programı ve AMOS 26.0 programından faydalanılmıştır. Örneklemin demografik verilerinin analizinde frekans analizi; bă̆ıml ve bă̆ımsız değişken arasındaki ilişkinin tespitinde ise korelasyon analizi yapılmıştır. Değişkenlerin faktöriyel yapısının belirlenmesinde temel bileşenler analizi, model uyumunun belirlenmesinde doğrulayıcı faktör analizi yapılmış, amirden duyulan tatmin ile görev performansı arasındaki nedensel ilişki AMOS ile regresyon analizi yapılarak belirlenmiştir. Analiz sonucunda çalışanların amirden tatminlerinin görev performanslarını pozitif yönde anlamlı olarak etkilediği tespit edilmiştir. Ulaşılan sonuçlar sosyal mübadele kuramı çerçevesinde tartışılmış ve gelecek araştırmacılara önerilerde bulunulmuştur.
\end{abstract}

Anahtar Kelimeler: Amirden Tatmin, Görev Performansı, Savunma Alanı.

\section{DOES THE SATISFACTION OF EMPLOYEES FROM THE SUPERVISOR AFFECT THEIR TASK PERFORMANCE? A RESEARCH IN AN INSTITUTION IN THE FIELD OF DEFENSE}

\begin{abstract}
This study aims to reveal the relationship between employee satisfaction and task performance. One of the successors of job satisfaction is task performance. The fact that there is a positive relationship between the employees and their supervisors enables employees to develop a positive attitude towards the workplace and his supervisor. Based on the principle that attitudes lead to behaviors, it can be said that positive attitudes of employees such as job satisfaction will result in an increase in performance by reflecting on their behaviour. In order to test this relationship, data were collected through 274 employees of an institution operating in the field of defense. SPSS 22.0 statistical package program and AMOS 26.0 program were used in the analysis of the data obtained in the research. The analysis of demographic data of the sample was tested by frequency analysis, and the relationship between the dependent and independent variables was tested by correlation analysis. Principal component analysis was used in determining the factorial structure of variables, confirmatory factor analysis was performed to determine the model fit, and the casual relationship between satisfaction from the supervisor and task performance was determined by regression analysis with AMOS. As a result of the analysis, it has been determined that the satisfaction of the employees with the supervisor has a significant positive effect on their task performance. The results were discussed within the framework of social exchange theory and suggestions were made to future researchers.
\end{abstract}

Keywords: Satisfaction From Supervisor, Task Performance, Field of Defense.

\footnotetext{
* Dr., JSGA, Güvenlik Bilimleri Enstitüsü, mehmetkahya@ jandarma.gov.tr, https://orcid.org/00000002-1455-3744.
} 


\section{GíRiş}

Çalışan tatmini denildiğinde akla ilk iş tatmini gelmektedir. Alanyazında iş tatmininin öncülleri ve ardılları üzerine birçok araştırma yapılmıştır. İş tatminin ardıllarından birisi de performanstır. İnsan ilişkileri hareketinin ortaya çıkışından bu yana, tatmin ile performans arasındaki ilişki bilimsel alanda araştırılmaktadır (Judge, Thoresen, Bono ve Patton, 2001). Alanyazında yapilan taramada çalışanların genel iş tatmini ve görev performansı arasındaki ilişkiyi inceleyen birçok araştırma (Ceylan ve Ulutürk, 2006; Fisher, 2003; Judge vd., 2001; Keaveney ve Nelson, 1993; Petty, McGee ve Cavender, 1984; Shore ve Martin, 1989) bulunmasına rağmen, iş tatminin alt boyutlarından birisi olan amirden tatmin ile görev performansı arasındaki ilişkiyi inceleyen çalışma sayısının (Ang, Van Dyne ve Begley, 2003; Iaffaldano ve Muchinsky, 1985; Zhang ve Zheng, 2009) daha az olduğu görülmüştür. Yapılan incelemede katı kuralların ve hiyerarşik yapılanmanın olduğu savunma alanında çalışanların amirden tatminiyle görev performansları arasındaki ilişkiyi inceleyen bir araştırma ise tespit edilememiştir. Oysaki savunma alanı ülkelerin bekasıyla, iç ve dış güvenliği sağlamada aktif rol alan, çalışanların hayatının söz konusu olduğu bir alandır. Bu alanda çalışanların, amirlerinin vereceği bir emirle ölüme gidebilecekleri dikkate alındığında çalışanların amirlerine olan sevgi, saygı ve amirlerinden tatminlerinin performanslarını önemli oranda etkileyebileceği değerlendirilmektedir.

Savunma alanında faaliyet gösteren bir örgütün etkin ve verimli bir şekilde hedeflerine ulaşabilmesi için, çalışanların görevlerini en iyi seviyede yerine getirmesi, yani performanslarının yüksek olması beklenir. Çalışanların performanslarının yüksek olması, tatminlerinin yüksek olmasına bağlıdır (Judge vd., 2001). Dolayısıyla savunma alanında çalışan bireylerin amirden tatminlerinin görev performanslarına etkisinin incelenmesinin önemli olduğu değerlendirilerek yazına katkı sağlamak maksadıyla bu araştırmanın yapılmasına karar verilmiştir.

Araştırmada öncelikle sosyal mübadele kuramı çerçevesinde amirden tatmin ile görev performansı arasındaki ilişki açıklanarak hipotez oluşturulmuş, müteakiben oluşturulan hipotez test edilmiştir. Elde edilen bulgular kuramsal yazınsal bağlamda tartış1larak, müteakip araştırmalar için önerilerde bulunulmuştur.

\section{AMIRDEN DUYULAN TATMIN VE GÖREV PERFORMANSI ARASINDAKİ İLIŞKİ}

İş tatmini çalışanların yaptıkları işten memnuniyet duymalarını veya işlerinin ve performanslarının değerlendirilmesi sonucunda olumlu duygusal durumlarını ifade 
eder (Locke, 1970; Schmidt, 2007; Shaikh, Bhutto ve Maitlo, 2012). İş tatmini genel olarak işin kendisinden, ücret, terfi, amir ve iş arkadaşlarından duyulan tatminden oluşur (Fisher, 2003). İş tatminin ardıllarından birisi ise performanstır (Edwards, Bell, Arthur ve Decuir, 2008). Bilimsel alanda en çok incelenen konulardan birisi tatmin ile performans arasındaki ilişkidir (Judge vd., 2001). Örgütsel tutum ve davranışların geliştirilmesinde iş tatmini ve iş performansının önemli olduğu öne sürülmektedir (Bartlett ve Kang, 2004; Zhang ve Zheng, 2009).

Çalışmalar, tatmin ile performans arasındaki ilişkiye yönelik ışık tutmasına rağmen ilişkinin nedensel yönüne yönelik farklı bulgulara ulaşılmıştır (Brayfield ve Crockett, 1955; Iaffaldano ve Muchinsky, 1985; Judge vd., 2001; Robbins ve Judge, 2013). Alanyazında iş tatmini ile iş performansı arasında , 17 ile ,53 arasında değişen oranda korelasyon olduğunu gösteren çalışmalar bulunmaktadır (Akkoç, Çalışkan ve Turunç, 2012; Iaffaldano ve Muchinsky, 1955; Judge vd., 2001; Spector vd., 2009). Harrison, Newman ve Roth (2006) farklı zaman serisi tasarımlar kullanarak yaptıkları çalışmada tatminin performansa yol açmasının, performansın tatmine yol açmasına göre çok daha olası olduğunu tespit etmiştir. Iaffaldano ve Muchinsky (1985) yaptıkları meta-analiz çalışmasında tatminle performans arasında ,17'lik bir korelasyon bulunduğunu tespit etmiştir. Genel olarak alanyazında tutumların davranışları etkileyeceğine yönelik birçok çalışma bulunmaktadır. Örneğin, Fisher (2003) mutlu ve memnun çalışanların işlerinde daha üretken olduğunu ve görev performanslarının daha yüksek olduğunu tespit etmiştir. Kraus (1995) tutum-davranış araştırmalarını incelediği meta-analiz çalışması sonucu, tutumların davranışları anlamlı olarak yordadığı sonucuna ulaşmıştır. Ajzen (2005) tutum ve davranışın tutarlı olması durumunda tatmin ve performans arasındaki ilişkinin daha güçlü olacağını belirtmektedir. Robbins ve Judge (2013) üç yüzden fazla çalışmayı inceleyerek yaptıkları çalışmada tatmin ve performans arasında pozitif bir korelasyon bulunduğunu tespit etmiştir. Sosyal psikolojik bakış açısı da tutumların davranışları etkilediğini öne sürmektedir (Ajzen ve Fishbein, 1980; Allen ve Meyer, 1990; Cohen, 1991; Yavaş ve Bodur, 1999). Yazında yapılan bunca araştırmaya rağmen, iş tatmini ile iş performansının birbirlerini nasıl etkilediği hala tam olarak anlaşılamamıştır (Judge vd., 2001). Teorik açıklamalar ve yazında yapılan ampirik çalışma bulgularının incelenmesi sonucu, iş tatminin performansa yol açmasının, performansın iş tatminine yol açmasına göre çok daha muhtemel olduğu öngörülmektedir.

Borman ve Motowidlo (1993, 1997) iş performansını görev ve bağlamsal performans olmak üzere iki-faktörlü bir yapı ile açıklamıştır. Borman ve Motowidlo (1997) amirlerin çalışanların genel performanslarını değerlendirmede 
görev performanslarını ve bağlamsal performanslarını eşit seviyede dikkate aldığını belirtmektedir. Görev performansı "çalışanın veya işgörenin kendisinden beklenen işi yapması veya tamamlaması" (Tekingündüz, Top ve Seçkin, 2015: 41), "bireyin görevini icra etmek maksadıyla harcadığı çabaya karşılık ulaştığı başarı düzeyi” (Yıldız, Savcı ve Kapu, 2014: 236) ya da "rol verilen, bir işi diğerinden ayıran ve örgütün teknik özüne katkıda bulunan davranışlar" (Borman ve Motowidlo, 1993: 100) şeklinde tanımlanmaktadır. Görev performansı kısaca, çalışanın örgütün belirlediği görevleri yerine getirmesi ve örgütün hedeflerine yönelik katkıda bulunması olarak ifade edilebilir. Fisher, (2003) çalışanların pozitif düşünceye sahip olmasının görev performansları üzerinde olumlu etki yaratacağını ve böylece çalışanların çoğu farklı görevi rahatlıkla yerine getirebileceklerini öne sürer.

Tatminle performans arasındaki ilişki çeşitli teorik yaklaşımlar (sosyal mübadele teorisi, eşitlik teorisi, beklenti teorisi, karşılıklılık teorisi, sosyal bilişsel teori, vb.) ile açıklanmaktadır (Brayfield ve Crockett, 1955; Locke, 1976; Vroom, 1964). Tatminle görev performansı arasındaki ilişkiyi açıklamada kullanılabilecek teorilerden birisi de sosyal mübadele teorisidir. Sosyal mübadele teorisi sosyal ilişsilerde iki taraf arasında bir değiş tokuşun (kaynak değişimi) söz konusu olduğunu ve bireylerin sosyal değişimlerden aldıkları şeyleri dengelemek için gayret gösterdiklerini ileri sürer (Adam, 1965; Blau, 1964). Sosyal mübadele teorisine göre çalışanlar arzu ettikleri hedeflere ulaşmak için başkalarıyla (iş arkadaşı, amir, örgüt, vb.) iş birliği yaparlar. Teoriye göre bireyler çaba sarf ederek bir hizmet üretmekte, bunun karş1lı̆̆ 1 olarak örgüt de bireylere maddi ve manevi karşılık vermekte, dolayısıyla örgütle çalışan arasında bir değiş-tokuş (mübadele) gerçekleşmektedir (Blau, 1964). Edwards ve arkadaşları (2008: 448) çalışanların tatmini yüksek olduğunda, karşılık verme aracı olarak görev performansı gibi işle ilgili görevlerde daha fazla çalışabileceklerini belirtmektedirler. Dolayısıyla performansı artırmak için çalışanların motive edilmesi, tatmin edilmesi ve örgütteki diğer üyelerle (iş arkadaşı ve amirler) iyi sosyal ilişkiler geliştirmesi ihtiyacının bulunduğu öne sürülmektedir (Swanson ve Holton, 2001). Bu durumda çalışanın tatmin duygusunun yüksek olmasının davranışına yansıyacağı ve karşılık olarak performansını artıracağı değerlendirilebilir.

$\mathrm{Bu}$ çalışma tutumların davranışlara yol açtığı görüşünü benimsemekte ve amirden tatminin görev performansını artıracağını öne sürmektedir. Tutum ve davranış arasındaki hedef ilişkisi dikkate alındığında genel iş tatmininin bir faktörü olan amirden tatminle performansin bir türü olan görev performansı arasındaki ilişkiye dayalı olarak aşağıda belirtilen hipotez oluşturulmuştur: 
H1: Çalışanların amirlerinden tatmini görev performanslarını pozitif yönde anlamlı olarak etkilemektedir.

\section{YÖNTEM}

\section{1. Örneklem ve İşlem}

Çalışmanın evrenini savunma alanında ülke çapında faaliyet gösteren ve yaklaşık 100000 çalışanı bulunan bir kurumun personeli oluşturmaktadır. Araştırma evreninin sayısı kurumun iç haberleşme ağı (intranet) üzerinden belirlenmiştir. Araştırmada örneklem seçim tekniği olarak olasıl1klı olmayan örneklem tekniklerinden kolayda örnekleme yöntemi; veri toplama aracı olarak nicel veri toplama tekniklerinden anket tekniği kullanılmıştır. Veri toplamak maksadıyla hazırlanan anket ilgili kurumdan izin alınmasını müteakip, araştırma ile ilgili açıklayıcı bir bilgi içerecek şekilde kurumun iç haberleşme ağ (intranet) üzerinden sisteme yüklenmiş ve gönüllük esasına göre kurum personelinin anketi doldurması talep edilmiştir. Çalışmanın örneklemi anketi doldurarak araştırmaya gönüllü olarak katılan 274 kurum çalışanından oluşmaktadır. 100000 kişilik bir araştırma evreninde \%95 güven aralığında örneklem sayısı 382 olarak hesap edilmiştir (Sekeran, 1992: 253). Fakat bu çalışmada yapılan faktör analizinde K-M-O değerinin ,50'nin üzerinde olduğu tespit edildiğinden, örneklem sayısının analiz için yeterli olduğu görülmüş ve analizler yapılmıştır (Field, 2013).

Araştırmada elde edilen verilerin analizinde SPSS 22.0 paket programı ve AMOS 26.0 programından faydalanılmıştır. Örneklemin demografik verilerinin analizinde frekans analizi; bağımlı ve bağımsız değişken arasındaki ilişkinin tespitinde ise korelasyon analizi yapılmıştır. Değişkenlerin faktöriyel yapısının belirlenmesinde temel bileşenler analizi, yapı geçerliliğinin belirlenmesinde yapısal eşitlik modellemesi ile doğrulayıcı faktör analizi, amirden duyulan tatmin ile görev performansı arasındaki nedensel ilişki regresyon analizi ile belirlenmiştir.

\section{2. Ölçekler}

Amirden Duyulan Tatmin Ölçeği. Çalışanların amirlerinden duydukları tatminin ölçümlenmesinde, Spector (1985) tarafından geliştirilen iş tatmin ölçeğinin amirden tatminini ölçümleyen maddelerinden faydalanılmıştır. Ölçeğin Türkçe'ye uyarlaması Sun (2002) tarafından yapılmış olup, ölçek 6 maddeden oluşmaktadır. Ölçek 7'li likert tipi ( $1=$ Kesinlikle katılmıyorum, 7=Kesinlikle katılıyorum) ve tek boyutludur. Ölçeğin örnek maddesi “Amirimi seviyorum” ifadesidir. Temel bileşenler analizi sonucu bir maddenin (Amirimin yaptığım işle ilgili 
düşüncelerime önem vermediğini hissediyorum) ölçekten çıkarılması sonucu ölçeğin güvenilirlik değeri (cronbach alpha- $\alpha$ ) ,91 olarak tespit edilmiştir.

Görev Performansı Ölçeği. Çalışanların görev performansının ölçümlenmesinde, Sigler ve Pearson (2000) tarafından geliştirilen görev performansı ölçeğinden faydalanılmıştır. Ölçeğin Türkçe'ye uyarlaması Çöl (2008) tarafindan yapılmış olup, ölçek tek boyutlu ve 4 maddeden oluşmaktadır. Ölçek 7'li likert tipi (1= Kesinlikle katılmıyorum, 7=Kesinlikle katılıyorum)'dir. Ölçeğin örnek maddesi "Görevlerimi tam zamanında tamamlarım" ifadesidir. Araştırmamızda kullanılan ölçeğin güvenilirlik (cronbach alpha- $\alpha$ ) değeri ,75 olarak tespit edilmiştir.

\section{BULGULAR}

Araştırmaya katılan kurum çalışanlarının tamamı erkek olup, yaş ortalaması 32,42 (s.s. 5,85) y1l; mesleki tecrübe ortalamas1 9,49 (s.s. 6,28) y1l ve bir üst kademedeki amirleriyle bir arada ortalama çalışma süresi 1,80 (s.s. 1,94) yıldır. Araştırmaya katılan çalışanların \%36,1'i ( $\mathrm{n}=99)$ lisans, \%29,6's1 $(\mathrm{n}=81)$ lise mezunu olup, $\% 80,7$ 'si ( $\mathrm{n}=221$ ) evlidir.

Ortak yöntem varyans problemini test etmek için Harman'ın temel bileşenler analizi tek faktörlü testi uygulanmış, kullanılan ölçeklerin maddeleri tek bir faktöre yüklenerek faktör analizi yapılmıştır. Hair ve arkadaşları (2019: 735) ortak yöntem varyans probleminin bağımsız ve bağımlı değişkenin tek bir kaynaktan toplanmasından kaynaklanabileceğini öne sürerek, tek faktörde açıklanan varyans değerinin \%50'nin altında olması durumunda böyle bir problemin yaşanmayacağını ifade etmektedir. Yapılan analiz sonucunda açıklanan varyans değeri $\% 43,79$ olarak tespit edildiğinden bu çalışma için ortak yöntem varyans problemi olmadığ görülmüştür.

Örneklem sayısının yeterliliği ve verilerin faktör analizine uygunluğunu belirlemek maksadıyla K-M-O ve Bartlett Küresellik testleri yapılmıştır. Field (2013) örneklem sayısının yeterli olması için K-M-O değerlerinin ,50’nin üzerinde olması gerektiğini, ve verilerin faktör analizine uygunluğu için de Barttlet Küresellik testinin anlamlı olması gerektiğini belirtmektedir. Yapılan analiz sonucu örneklem sayısının yeterli olduğu ve verilerin faktör analizi için uygun olduğu tespit edilmiştir.

Amirden tatmin ölçeği ve görev performansı ölçeğinin faktöriyel yapısını tespit etmek maksadıyla varimax rotasyon yöntemiyle temel bileşenler analizi yapılmıştır (Neill, 2008: 6). Temel bileşenler analizi sonucunda görev performansı ölçeğinin 
maddelerinin tek faktör altında toplandığı görülmüştür. Ayrıca amirden tatmin ölçeğinin maddelerinin de tek faktör altında toplandığı, ancak 6'ncı maddenin (Amirimin yaptığım işle ilgili düşüncelerime önem vermediğini hissediyorum) faktör yükünün $(, 31)$ ve eşdoğrusallık değerinin $(, 10)$ kabul edilelen eşik değerin altında olması nedeniyle ölçekten çıkarılması gerektiği değerlendirilerek çıkarılmış ve analiz tekrarlanmıştır. Analiz sonucunda her iki ölçekte de tek faktörlü yapı elde edilmiştir.

Doğrulayıcı faktör analizinden önce ölçeklerin güvenilirlik ve geçerlilik (benzeşim ve ayrışım) analizleri yapılmıştır. Murphy ve Davidshofer (1988) güvenilirlik için değişkenlerin cronbach alpha $(\alpha)$ değerinin ,70 in üzerinde olması gerektiğini belirtmektedir. Güvenilirlik analizi sonucu amirden tatmin ölçeğinin güvenilirlik değeri ,91; görev performansı ölçeğinin güvenilirlik değeri ,75 olarak tespit edilmiştir. Hair ve arkadaşları (2019) benzeşim geçerliliği için açıklanan ortalama varyans (AVE) değerinin ,50'nin üstünde olması ve yap1 güvenilirliği (CR) değerinin de AVE değerinden büyük olması gerektiğini; ayrışım geçerliliği için ise AVEnin karekökünün korelasyon değerlerinden büyük olması veya yapılar arasındaki korelasyonların ,90'dan büyük olmaması gerektiğini belirtmektedir. Analiz sonucunda her iki ölçeğin güvenilir olduğu, benzeşim ve ayrışım geçerliliği sağladığı tespit edilmiştir. Temel bileşenler analizi sonucu elde edilen faktör yükleri ve eşdoğrusallık değerleri ile AVE ve CR değerleri Tablo-1 de gösterilmiştir.

Tablo-1. Değişkenlere Ait Faktör Yükleri $(\mathrm{n}=274)$

\begin{tabular}{|c|c|c|c|c|c|}
\hline Ölçek & Madde & $\begin{array}{c}\text { Faktör Yük } \\
\text { Değeri }\end{array}$ & Eşdoğrusallık & $\begin{array}{c}\text { K-M-O ve } \\
\text { Barttlet } \\
\text { Test Değeri }\end{array}$ & $\begin{array}{c}\text { AVE- } \\
\text { CR } \\
\text { Değeri }\end{array}$ \\
\hline \multirow{5}{*}{ Amirden Tatmin } & T_1 & ,87 & ,76 & \multirow{5}{*}{$\begin{array}{c}\text { KMO: ,87 } \\
\text { Yaklaşık } \chi^{2}: \\
972,3 \\
\text { df: } 10 \\
\text { anlamlilik: } \\
.000\end{array}$} & \multirow{5}{*}{$\begin{array}{c}\text { AVE: } \\
\text {,74 } \\
\text { Karekök } \\
\text { AVE: } \\
\text {,86 } \\
\text { CR: ,93 }\end{array}$} \\
\hline & T_2 & ,72 & 52 & & \\
\hline & T_3 & ,88 & ,78 & & \\
\hline & T_4 & ,88 & ,78 & & \\
\hline & T_5 & ,92 & 86 & & \\
\hline \multirow{4}{*}{ Görev Performansı } & P_1 & ,80 & ,64 & \multirow{4}{*}{$\begin{array}{c}\text { KMO: ,75 } \\
\text { Yaklaş1k } \chi^{2} \text { : } \\
314,8 \\
\text { df: } 6 \\
\text { anlamlılık: } \\
.000\end{array}$} & \multirow{4}{*}{$\begin{array}{c}\text { AVE: } \\
\text {,60 } \\
\text { Karekök } \\
\text { AVE: } \\
\text {,78 } \\
\text { CR: ,86 }\end{array}$} \\
\hline & P_2 & 63 & 40 & & \\
\hline & P_3 &, 85 & ,72 & & \\
\hline & P_4 & ,82 & ,66 & & \\
\hline
\end{tabular}


Temel bileşenler analizinde elde edilen faktör yapısını doğrulamak ve yapı geçerliliğini sağlamak maksadıyla AMOS 26 programı kullanılarak her bir değişken için ayrı ayrı ve her iki değişkendeki ifadelerin tek bir faktörde toplandığı bir model oluşturularak birincil düzey tek faktörlü model doğrulayıcı faktör analizi (DFA) yapılmıştır. Analiz sonucunda tüm ifadelerin tek bir faktörde toplandığ1 modelin uyum iyiliği değerlerinin model iyileştirme endekslerindeki iyileştirmeler yapılmasına rağmen düşük olduğu ve iyi uyum sağlamadığg görülmüştür. Amirden tatmin değişkeni ve görev performansı değişkeninin farklı yapılar olarak oluşturulduğu tek faktörlü model DFA analizi sonucunda uyum değerlerinin yeterli uyum sağladığı görülse de, incelenen model iyileştirme endeksleri amirden tatmin değişkeninin 2 ve 4'üncü maddeleri ve görev performansı değişkeninin 2 ve 4'üncü maddeleri arasında oluşturulacak bir ilişkinin faktörleri daha da iyileştireceği ve amirden tatmin değişkeninin ki-kare değerini 7,2 puan; görev performans1 değişkeninin ki-kare değerini 5,75 puan aşağı çekeceği görülmüştür. Belirtilen iyileştirmeler yapılarak tekrar DFA yapılmış ve değişkenlerin daha iyi uyum değerlerine sahip olduğu tespit edilmiştir. Analiz sonucunda, oluşturulan birincil düzey tek faktörlü modelin iyi/kabul edilebilir uyum değerlerine sahip olduğu tespit edilmiş ve değişkenlerin tek faktörlü yapıları doğrulanmıştır. Değişkenlere ait uyum iyiliği değerleri Tablo-2'de sunulmuştur.

Tablo-2. Değişkenlere Ait Birincil Düzey Tek Faktörlü DFA (n=274)

\begin{tabular}{|c|c|c|c|c|c|c|c|}
\hline Değişken & Model & $\Delta \chi^{2}$ & sd & $\Delta \chi^{2} / \mathrm{sd}$ & RMSEA & GFI & CFI \\
\hline \multirow[b]{2}{*}{$\begin{array}{c}\text { Tek Faktörlü } \\
\text { Model }\end{array}$} & İlk model & 325,24 & 27 & 12,04 & ,20 & ,77 &, 77 \\
\hline & $\begin{array}{c}\text { İyileştirme } \\
\text { sonrası model }\end{array}$ & 162,17 & 23 & 7,05 &, 15 & ,90 &, 89 \\
\hline \multirow[b]{2}{*}{ Amirden Tatmin } & İlk model & 18,52 & 5 & 3,70 &, 10 & ,97 & ,98 \\
\hline & $\begin{array}{c}\text { İyileştirme } \\
\text { sonrası model }\end{array}$ & 11,32 & 4 & 2,83 & ,08 & ,98 & ,99 \\
\hline \multirow[b]{2}{*}{$\begin{array}{c}\text { Görev } \\
\text { Performans1 }\end{array}$} & İlk model & 6,79 & 2 & 3,39 & ,09 & ,98 & ,98 \\
\hline & $\begin{array}{c}\text { İyileştirme } \\
\text { sonrası model }\end{array}$ & 1,04 & 1 & 1,04 & ,01 & ,99 & 1,00 \\
\hline
\end{tabular}

$* \Delta \chi^{2} / \mathrm{sd}$ (genel uyum modeli); RMSEA (yaklaşık hataların ortalama karekökü); GFI (iyilik uyum indeksi); CFI (karşılaştırmalı uyum indeksi)

İyi Uyum: $\Delta \chi^{2} / \mathrm{sd} \leq 3$; RMSEA $\leq, 05 ; \mathrm{GFI} \geq, 95 ; \mathrm{CFI} \geq, 99$

Kabul Edilebilir Uyum: $\Delta \chi^{2} / \mathrm{sd} \leq 4-5$; RMSEA $\leq, 08$; GFI $\geq, 90$; CFI $\geq, 95$ (Kaynak: Hair vd., 2019; Hu ve Bentler, 1999).

Değişkenler arasındaki korelasyonu belirlemeye yönelik yapılan korelasyon analizi sonuçları (değişkenlerin ortalaması ve standart sapması ile değişkenler arasındaki korelasyon değerleri) Tablo-3'de gösterilmiştir. 
Tablo-3. Değişkenler Arasındaki Korelasyon Analizi Sonuçları $(\mathrm{n}=274)$

\begin{tabular}{|c|c|c|c|c|c|c|c|c|}
\hline Değişken & Ort. & S.S. & Yaş & $\begin{array}{c}\text { Hizmet } \\
\text { Yılı }\end{array}$ & $\begin{array}{c}\text { Amirle } \\
\text { Çalıșma }\end{array}$ & Eğitim & $\begin{array}{c}\text { Amirden } \\
\text { Tatmin }\end{array}$ & $\begin{array}{c}\text { Görev } \\
\text { Performansı }\end{array}$ \\
\hline Yaş & 32,42 & 5,85 & 1 & & & & & \\
\hline Hizmet Y1l1 & 9,49 & 6,28 &, $95^{* *}$ & 1 & & & & \\
\hline Amirle Ç.Süre & 1,80 & 1,94 &, 03 &, 05 & 1 & & & \\
\hline Eğitim & - & - &, $49^{* * *}$ &, $\mathbf{5 3}^{* *}$ &, 00 & 1 & & \\
\hline Amirden Tat. & 5,35 & 1,55 &, 06 &, 10 & 07 & ,08 & 1 & \\
\hline Görev Perf. & 5,98 &, 78 &,- 04 &,- 01 &,- 09 &, 04 &, $22^{* *}$ & 1 \\
\hline
\end{tabular}

$* * \mathrm{p}<0.01$

Tablo-3 incelendiğinde demografik değişkenlerle (yaş, hizmet yıll, amirle çalışma süresi ve eğitim) bağımsız ve bağımlı değişken arasında herhangi bir ilişkinin bulunmadığ 1 , fakat bağımsız değişkenle (amirden tatmin) bağımlı değişken (görev performansı) arasında pozitif yönde zayıf bir ilişkinin bulunduğu $(\mathrm{r}=.22, \mathrm{p}<.01)$ görülmektedir.

Korelasyon analizi sonucu değişkenler arasında bir korelasyonun bulunması, aradaki ilişkinin nedensel olduğunu göstermez. Bu nedenle, değişkenler arasındaki nedensel ilişkinin belirlenmesine yönelik AMOS programı aracılığıyla regresyon analizi yapılmıştır (Hair vd., 2019: 643).

Regresyon analizi sonucu bağımsız değişken (amirden tatmin) ve bağıml değişken (görev performans1) kullanılarak kurgulanan modelin iyi uyum değerlerine sahip olduğu $\left(\Delta \chi^{2}=25,84 ; \mathrm{df}=24 ; \Delta \chi^{2} / \mathrm{sd}=1,07\right.$; RMSEA $=, 01$; GFI= ,98; CFI=1.00) tespit edilmiştir. Regresyon analizi sonucu değişkenler arasındaki nedensel ilişkiyi gösteren araştırma modeli Şekil-1'de sunulmuştur.

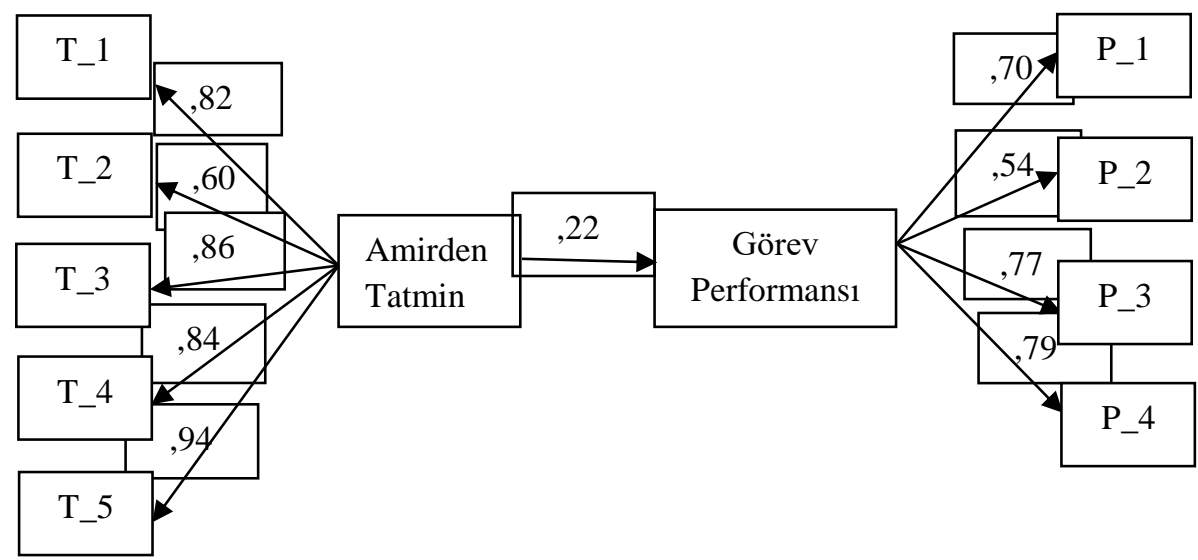

Şekil-1: Araştırma Modeli 
Analiz sonucunda çalışanların amirden tatmininin görev performansını pozitif yönde ve anlamlı olarak yordadığı tespit edilmiştir. Bu kapsamda $\mathrm{H} 1$ hipotezi desteklenmiştir.

\section{TARTIŞMA VE SONUÇ}

$\mathrm{Bu}$ çalışmanın amacı hiyerarşik bir yapılanmanın olduğu savunma alanında çalışanların amirden tatminleriyle görev performansları arasındaki ilişkiye 1şı tutmaktır. Bu bağlamda yapılan bu araştırma ile çalışanların amirden tatminin görev performanslarını olumlu yönde etkilediği ortaya konulmuştur. Örgütlerin temel amaçlarından birisi çalışanların performansını artırmaktır (Swanson ve Holton, 2001). Bunu sağlamanın yollarından birisinin de çalışanların genel olarak tatminini yüksek tutmaktær olduğu belirtilebilir. Teoriler, pozitif düşünceye sahip olmanın performans artışına yol açacağını öne sürer (Fisher, 2003). Ayrıca alanyazında çoğunlukla mutlu insanların daha üretken olacağını (tatmin performansa yol açar) ortaya koyan çalışmalar da bulunmaktadır (Keaveney ve Nelson, 1993; Shore ve Martin, 1989).

$\mathrm{Bu}$ çalışmada çalışanların amirden tatminlerinin yüksek olmasının görev performanslarını etkileyeceği hipotezi test edilerek doğrulanmıştır. Elde edilen sonuçların alanyazında daha önce yapılan çalışmalarla (Zhang ve Zheng, 2009; Iaffaldano ve Muchinsky, 1985; Robbins ve Judge, 2013) tutarlıdır olduğu görülmüş ve bu çalışmayla alanyazında öne sürülen tatmin performansa yol açar söylemi desteklenmiştir.

$\mathrm{Bu}$ çalışmayla sosyal mübadele teorisine kuramsal katkı sağlanmıştır. Sosyal mübadele teorisine göre çalışanlar yapmış oldukları hizmetin karşılığında örgütten maddi ve manevi bir karşı1ık alması nedeni ile bu ilişki kapsamında bir nevi değiştokuş yaşandığı öne sürülebilir. Çalışanların yüksek performansla çalışmaları çalışma arkadaşları ve amirleriyle iyi ilişkiler geliştirmiş olmasına ve huzurlu bir ortamda görevlerini istekle yapmalarına bağlıdır. $\mathrm{Bu}$ bağlamda elde edilen çalışanların amirlerinden tatmin olması durumunda görev performanslarını yükseltmeleri sosyal mübadele teorisinin öne sürdüğü değiş-tokuşu ortaya çıkaracaktır. Şöyle ki, çalışan amirinden memnun olduğundan pozitif düşünceye sahip olacak ve çalışma ortamından zevk alacak, görev performansını yükseltmesiyle de örgütün arzu ettiği üretkenlik ve verimlilik artışı elde edilecektir. Böylece teorinin öne sürdüğü karşılıklı iyilik ve iş birliği gerçekleşecektir.

$\mathrm{Bu}$ çalışmayla uygulamaya da katkı yapılmıştır. Bu çalışma, savunma alanında çalışanların amirlerinden tatminleriyle görev performansları arasındaki ilişkiyi 
inceleyen öncü çalı̧̧malardan birisidir. Bu çalışmayla örgütlerin arzu ettikleri çalışan performansını artırmanın yollarından birisinin çalışanların amirlerinden tatminlerini artırmaktan geçtiği ortaya konulmuştur. Savunma alanı, ülke bekasına yönelik görev yapılan, çalışanların iç ve diş güvenliği sağlamada yüksek performans göstermelerini gerektiren ve yapılan hatanın telafisinin zor olduğu bir alandır. Bu nedenle çalışanların amirleriyle arasındaki ilişkilerin pozitif olması, çalışanın işyerine ve amirine karşı olumlu tutum takınmasına ve karşılık olarak görevini en iyi şekilde icra etmesine yol açacaktır. Dolayısıyla savunma alanında faaliyet gösteren örgütlerin, bu çalışmada elde edilen sonuçları göz önünde bulundurarak insan kaynakları yönetimi uygulamalarında (performans değerleme, eğitim ve geliştirme, ücret yönetimi) dikkate almasının ve pozitif bir amir-çalışan ilişkisi geliştirme yönünde uygulamalar yapmasının, örgütün arzu ettiği hedeflerine ulaşmasını kolaylaştıracağı öne sürülebilir.

Araştırmanın bazı varsayımları ve kısıtları bulunmaktadır. Araştırmaya katılan deneklerin anketi doldurdukları zamanda sağlıklı oldukları, herhangi bir psikolojik rahatsızlıkları bulunmadığı ve anketi objektif doldurdukları varsayılmıştır. Araştırma kesitsel bir çalışma olup, veriler tek seferde ve deneklerin kendilerinden toplanmıştır. Müteakip araştırmalarda bağımsız değişkenlerle bağımlı değişkenlerin farklı zamanlarda toplanarak boylamsal çalışma yapılması ve çalışanların görev performansının belirlenmesinde bağlı oldukları bir üst amir tarafindan değerlendirme yapılmasının daha uygun olacağı değerlendirilmektedir.

Konu ile ilgilenen müteakip araştırmacılara çalışanların amirlerinden tatminleriyle görev performansları arasındaki ilişkide örgütsel bağlılıklarının aracılık etkisi ile örgütsel adalet, amir-çalışan uyumu ve lider-üye etkileşiminin düzenleyici etkisinin incelenmesi önerilebilir. Çalışanların amirlerinden tatmin olması durumunda genel olarak memnuniyetlerinin yüksek olacağ1 ve çalıştığ örgüte de olumlu bakacağı, bu durumda çalıştığı örgüte bağlılığının artacağ değerlendirilmektedir. Çalışanın örgütüne bağlılığının artması performansını artırmasına ve görevini en iyi şekilde yerine getirmek için çaba göstermesine yol açabilir. Hatta daha ileri seviyede çalışanın, çalıştığı örgütün yararına örgütsel vatandaşlık davranışı göstermesini sağlayabilir. Bu ilişkiye örnek olarak Zhang ve Zheng (2009)'in yaptıkları çalışma gösterilebilir. Zhang ve Zheng (2009) yaptıkları çalışmada çalışanların amirden tatminleriyle görev performansları arasında çalışanların duygusal bağl11ıklarının aracılık etkisi bulunduğunu tespit etmiştir.

Öte yandan amirden tatmini yüksek olan çalışanın, çalıştığı örgütteki adalet algıs1, bağlı olduğu amiriyle uyumu ya da lider-üye etkileşimi yüksekse görev 
performansının da yüksek olacağı; düşükse görev performansının da düşük olacağ 1 değerlendirilmektedir. Lider-üye etkileşimi teorisi lider-çalışan ilişkisinin kalitesinin kaynak değişimini gerektirdiğini öne sürer (Graen ve Scandura, 1987). Dolayısıyla, çalışanlar amirleri ve iş arkadaşları ile ilişkilerinden memnun kaldıkça, iş arkadaşlarına yardım ederek ve işin gerektirdiklerinin ötesine geçerek örgütsel vatandaşl1k davranışı gibi sosyal davranışlarda bulunarak karşıllık verebilirler (Edwards vd., 2001). Aynı argümanların görev performansını belirlemede algılanan adalet ve karşılıklılık için de geçerli olabileceğini söylemek mümkündür. Ayrıca amir ve iş arkadaşlarından duyulan memnuniyetin görev performansından ziyade bağlamsal performansı etkilemesi ihtimali de bulunmaktadır. Örneğin, Edwards ve arkadaşları (2008: 454-455) 444 çalışan üzerinde yapmış oldukları çalışmada amirden tatminle görev performansı arasında anlamlı bir ilişki tespit edememiş $(r=, 09 ; \gamma=, 22 ; \mathrm{p}>.05)$, fakat çalışanların amirden tatminleriyle bağlamsal performansları arasında ise anlamlı bir ilişki (r= ,20; $\gamma=, 36 ; \mathrm{t}=2,83 ; \mathrm{p}<.05)$ tespit etmiştir. Bu bağlamda müteakip araştırmacılara çalışanların amirden tatminleriyle bağlamsal performansları arasındaki ilişkinin de incelenmesinin yazına katkı sağlayabileceği değerlendirilmektedir.

Bu çalışma Jandarma ve Sahil Güvenlik Akademisi Bilimsel Araştırma ve Yayın Etiği Kurulu'nun 16.06.2020 tarihli ve 2020/6 sayıl kararl ile etik açıdan uygun bulunmuştur. 


\section{KAYNAKÇA}

Adams, J.S. (1965). Inequity in social exchange. L. Berkowitz (Ed.) Advences in Experimental Social Psychology (s.s. 267-299), 2. Bask1, New York: Academic Press.

Ajzen, I. ve Fishbein, M. (1980). Understanding attitudes and predicting social behavior. Englewood Cliffs, NJ: Prentice-Hall.

Ajzen, I. (2005). Attitudes, personality, and behavior. (2nci baskı). Chicago, IL: Dorsey Press.

Akkoç, İ., Çalışkan, A. ve Turunç, Ö. (2012). Örgütlerde gelişim kültürü ve algılanan örgütsel desteğin iş tatmini ve iş performansına etkisi. Yönetim ve Ekonomi: Celal Bayar Üniversitesi İktisadi ve İdari Bilimler Fakültesi Dergisi, 19(1), 105-135.

Allen, N.J. ve Meyer, J.P. (1990). The measurement and antecedents of affective, continuance and normative commitment to the organization. Journal of Occupational Psychology, 63, 1-18.

Ang, S., Van Dyne, L. ve Begley, T.M. (2003). The employment relationshipsof foreign workers versus local employees: A field study of organizational justice, job satisfaction, performance and OCB. Journal of Organizational Behavior, 24, 561-583.

Bartlett, K.R. ve Kang, D. (2004). Training and organizational commitment among nurses following industry and organizational change in New Zealand and the United States. Human Resource Development International, 4, 423-440.

Blau, P. (1964). Exchange and power in social life. New York: Wiley.

Borman, W.C. ve Motowidlo, S.J. (1993). Expending the criterion domain to include elements of contextual performance. N. Schmitt ve W.C. Borman (Ed.) Personnel Selection in Organizations (s.s. 71-98), San Francisco, CA: JosseyBass.

Borman, W.C. ve Motowidlo, S.J. (1997). Task performance and contxtual performance: The meaning for personnel selection. Human Performance, 10, 99-109.

Brayfield, A.H. ve Crockett, W.H. (1955). Employee attitudes and employee performance. Psychological Bulletin, 52, 396-424. 
Ceylan, A. ve Ulutürk, Y.H. (2006). Rol belirsizliği, rol çatışması, iş tatmini ve performans arasındaki ilişkiler. Doğuş Üniversitesi Dergisi, 7(1), 48-58.

Cohen, A. (1991). Career stage as a moderator of the relationships between organizational commitment and its outcomes: A meta-analysis. Journal of Occupational Psyhology, 64, 253-268.

Çöl, G. (2008). Algılanan güçlendirmenin işgören performansı üzerine etkileri. Doğuş Üniversitesi Dergisi, 9(1), 35-46.

Edwards, B.D., Bell, S.T., Arthur, W. ve Decuir, A.D. (2008). Relationships between facets of job satisfaction and task and contextual performance. Applied Psychology, 57(3), 441-465.

Field, A. (2013). Discovering statistics using IBM SPSS statistics. (4. Bask1), ABD: Sage.

Fisher, C.D. (2003). Why do lay people believe that satisfaction and performance are correlated? Possible sources of a commonsense theory. Journal of Organizational Behavior, 24(6), 753-777.

Graen, G.B. ve Scandura, T.A. (1987). Toward a psychology of dyadic organizing. Research in Organizational Behavior, 9, 175-208.

Harrison, D.A., Newman, D.A. ve Roth, P.L. (2006). How important are the job attitudes? Meta-analitic comparisons of integrative behavioral outcomes and time-sequences. The Academy of Management Journal, 49(2), 305-325.

Hair, J.F., Balck, W.C., Babin, B.J. ve Anderson, R.E. (2019). Multivariate data analysis. (8. Baskı), United Kingdom: Cengage Learning.

Hu, L.T. ve Bentler, P.M. (1999). Cut off criteria for fit indexes in covariance structure analysis: Conventional criteria versus new alternatives. Structural Equation Modeling, 6(1), 1-55.

Iaffaldano, M.T. ve Muchinsky, P.M. (1985). Job satisfaction and job performance: A meta-analysis. Psychological Bulletin, 97, 251-273.

Judge, T.A., Thoresen, C.J., Bono, J.E. ve Patton, G.K. (2001). The job satisfaction-job performance relationship: A qualitative and quantative review. Psychological Bulletin, 127(3), 376-407. 
Keaveney, S.M. ve Nelson, J.E. (1993). Coping with organizational role stress: Intrinsic motivational orientation, perceived role benefits, and psychological withdrawal. Journal of the Academy of Marketing Science, 21, 113-124.

Kraus, S.J. (1995). Attitudes and the prediction of behavior: A meta-analysis of the empirical literature. Personality and Social Psychology Bulletin, 21, 58-75.

Locke, E.A. (1970). Job satisfaction and job performance: A theoretical analysis. Organizational Behavior and Human Performance, 5, 484-500.

Locke, E.A. (1976). The nature and the causes of job satisfaction. M.D. Dunnette (Ed.) Handbook of Industrial and Organizational Psychology (s.s. 1297-1349), Chicago, IL: Rand McNally.

Murphy, K.R. ve Davidshofer, C.O. (1988). Psychological testing: Principles and applications. Englewood Cliffs, N.J.: Prentice-Hall.

Petty, M.M., McGee, G.W. ve Cavender, J.W. (1984). Ameta-analysis of the relationships between individual job satisfaction and individual performance. Academy of Management Review, 9, 712-721.

Robbins, P.S. ve Judge, A.T. (2013). Örgütsel davranış. 14. Basımdan çeviri, İ. Erdem (Çev. Ed.), Ankara: Nobel Akademi Yayıncılık.

Schmidt, S.W. (2007). The relationship between satisfaction with workplace training over all job satisfaction. Human Resource Development Quarterly, 18(4), 481-498.

Sekeran, U. (1992). Research methods for business: A skill building approach. (2. Bask1), USA: John Wiley \& Sons.

Shaikh, M.A., Bhutto, N.A. ve Maitlo, Q. (2012). Facets of job satisfaction and its association with performance. International Journal of Business and Social Science. 3(7), 322-326.

Shore, L.M. ve Martin, H.J. (1989). Job satisfaction and organizational commitment in relation to work performance and turnover intentions. Human Relations, 42, 625-638.

Sigler, T.H. ve Pearson, C. M. (2000). Creating an empowering culture: Examining the relationship between organizational culture and perceptions of empowerment. Journal of Quality Management, 5(1), 27-52. 
Spector, P.E. (1985). Measurement of human service staff satisfaction:

Development of the job satisfaction survey. American Journal of Community Psychology, 13(6), 693-713.

Spector, P.E., Judge, T.A., Parker, S., Colbert, A.E., Heller, D. ve Ilies, R. (2009). "İş tatmini: Kültürlerarası bir inceleme". N. Anderson, D.S. Öneş, H.K. Sinangil ve C. Viswesvaran (Ed.), Endüstri, İş ve Örgüt Psikolojisi El Kitabl, B. Öz (çev.), (s.s. 29-60), 2. Cilt, 1. Baskı, İstanbul: Literatür Yayıncılık.

Sun, Ö. (2002). İş doyumu üzerine bir araştırma: Türkiye Cumhuriyet Merkez Bankası (Yayımlanmamış Uzmanlık Yeterlilik Tezi), Türkiye Cumhuriyet Merkez Bankası Banknot Matbaası Genel Müdürlüğü, Ankara.

Swanson, R.A. ve Holton, E.F. (2001). Foundations of human resource development. San Francisco: Berrett-Koehler.

Tekingündüz, S., Top, M. ve Seçkin, M. (2015). İş tatmini, performans, iş stresi ve işten ayrılma niyeti arasındaki ilişkilerin incelenmesi: Hastane örneği. Verimlilik Dergisi, 48(4), 39-64.

Vroom, V.H. (1964). Work and motivation. New York: Wiley.

Yavaş, U. ve Bodur, M. (1999). Satisfaction among expatriate managers: Correlates and consequences. Career Development International, 4(5), 261-269.

Yıldız, S., Savcı, G. ve Kapu, H. (2014). Motive edici faktörlerin çalışanların iş performansına ve işten ayrılma niyetine etkisi. Yönetim ve Ekonomi, 21(1). 233249.

Zhang, J. ve Zheng, W. (2009). How does satisfaction translate into performance? An examination of commitment and cultural values. Human Resource Development Quarterly, 20(3), 331-351. 